Research Article

\title{
Field Efficacy of Nicotiana tabacum L. var Virginia Extract against Coffee Borer Beetle (Hypothenemus hampei) Attacking Coffee Berries in Plantation Area
}

\author{
Andre Fahriz Perdana Harahap, ${ }^{1}$ Ahmad Fauzantoro, ${ }^{2}$ Haryuni Haryuni, ${ }^{3}$ \\ Tyas Sumarah Koernia Dewi, ${ }^{3}$ Endang Suprapti, ${ }^{3}$ Muhammad Yusuf Arya Ramadhan, \\ Young Je Yoo, ${ }^{4}$ and Misri Gozan (iD) \\ ${ }^{1}$ Bioprocess Engineering Program, Chemical Engineering Department, Faculty of Engineering, Universitas Indonesia, \\ Depok 16424, Indonesia \\ ${ }^{2}$ Laboratory for Biotechnology, Agency for the Assessment and Application of Technology (BPPT), 630 Bld., \\ Kawasan Puspiptek Serpong, Tangerang Selatan 15314, Indonesia \\ ${ }^{3}$ Faculty of Agriculture, Tunas Pembangunan University, Balekambang Lor No. 1, Manahan, Surakarta 57139, \\ Central Java, Indonesia \\ ${ }^{4}$ School of Chemical \& Biological Engineering, Seoul National University, 599 Gwanak-ro, Gwanak-gu, \\ Seoul 151-744, Republic of Korea \\ ${ }^{5}$ Research Centre for Biomedical Engineering, Universitas Indonesia, Depok 16424, Indonesia
}

Correspondence should be addressed to Misri Gozan; mrgozan@gmail.com

Received 20 June 2020; Revised 16 July 2020; Accepted 11 August 2020; Published 28 August 2020

Academic Editor: Yong In Kuk

Copyright (c) 2020 Andre Fahriz Perdana Harahap et al. This is an open access article distributed under the Creative Commons Attribution License, which permits unrestricted use, distribution, and reproduction in any medium, provided the original work is properly cited.

\begin{abstract}
The extract of Nicotiana tabacum L. var Virginia origin of Ponorogo (EHRE-Nt) was applied under field conditions against the coffee borer beetle Hypothenemus hampei (CBB). Three extract formulations containing 150, 300, and $450 \mathrm{ml}$ of EHRE-Nt in 100 liters of water were prepared and sprayed on 0.5 hectares each. A nontreatment was applied as a control on 0.5 hectares of plantation. The intensity of the CBB attacks was observed for six weeks on a Robusta coffee plantation in the Kalibening area, South Semarang, Central Java, Indonesia. An extract formulation containing $450 \mathrm{ml}$ of EHRE-Nt resulted in the lowest intensity of $\mathrm{CBB}$ attacks from weeks one to six (1.6\% to $2.2 \%)$. The attacks of the control field were $11.3 \%$ to $13.5 \%$. The highest efficacy level of 85.4\% was obtained with the $450 \mathrm{ml}$ EHRE-Nt formulation. These results demonstrate that EHRE-Nt has potential as a bioinsecticide for coffee berries from CBB attacks.
\end{abstract}

\section{Introduction}

The coffee borer beetle Hypothenemus hampei Ferrari (abbreviated as CBB) is the major coffee pest that is harmful for coffee berries on the coffee plantation. Globally, it has been causing 25\% annual losses in the production of harvest coffee over US $\$ 500$ million in the world [1]. CBBs attacks also induced substantial losses on coffee plantations in Indonesia. For an average yield of total Indonesian coffee about 1.25 million hectares, it is more than US\$6.7 million per year of losses due to CBBs attack. So, the yield losses in a hectare are about $50 \mathrm{~kg}$ per year [2].

Adult females of CBBs make holes in the endosperm of coffee beans to put their eggs into the holes. The eggs are transformed into larvae in only around four days. The larvae are then proliferated as the pupae after 15 days and then come out from the coffee berries as mature beetles after seven days $[3,4]$. So, between eggs and adult phases, they got the feed and nutrients from the coffee berries where they live $[5,6]$. 
The proliferation of CBBs is also influenced by the temperature and availability of coffee berries on the coffee plantation. The $\mathrm{CBBs}$ eggs are optimally proliferated at $30-32^{\circ} \mathrm{C}$, while the larvae, pupae, and adult beetles are at $27-30^{\circ} \mathrm{C}$. The holes in coffee berries are made by adult female beetles at the temperature range of $20-33^{\circ} \mathrm{C}$, whereas at a temperature below $15^{\circ} \mathrm{C}$ or above $35^{\circ} \mathrm{C}$, the beetles fail to make holes in coffee berries, or the holes could be made by them without any eggs inside. The peak of the intensity of CBBs attack on coffee berries on the plantation is around May to July, where the coffee plants mostly produce coffee berries at these periods $[7,8]$.

The CBBs can attack both immature and mature coffee berries. The damaged immature coffee berries due to CBBs attack are then rotten and fall. Differently, the attack of CBBs on the mature coffee berries caused flawed coffee beans [9]. In both cases, the coffee bean quality and yield productivity are significantly jeopardized if the insects are not eradicated.

The use of synthetic insecticide is widely known to eradicate CBBs attack on a coffee plantation. A carbamate group from widely used commercial pesticides with the active compound of $85 \%$ carbaryl is an example of a white crystalline synthetic insecticide. This insecticide effectively kills CBBs beetle pest by contact and stomach poisoning as the effect from its active compound. However, indiscriminate use of carbaryl and also carbofuran insecticide leaves the residue and leads to the emergence of resistant to many insects such as the peach potato aphid Myzus persicae [10], the German cockroach Blattella germanica [11], the striped stem borer Chilo suppressalis [12], and also Hypothenemus hampei $[13,14]$. The hazardous residue can be absorbed into the coffee beans and can also contaminate the environment for a long-term period [13]. Therefore, the use of synthetic insecticides should be substituted by natural insecticides (bioinsecticides) due to the low toxicity of bioinsecticides and its safe application for the environment.

Some methods for controlling CBBs were achieved by integrated pest management (IPM). They are, firstly, the application of the biological control agents as natural enemies of CBBs; secondly, sanitation harvesting of coffee berries as a CBBs food source which is left on the trees and the soil surface after harvesting; and thirdly, the application of the bioinsecticides to eradicate or prevent the CBBs attack $[15,16]$.

The use of soil fungus Beauveria bassiana against CBBs was reported in Columbia [17] and also in India [18]. The results showed a significant decrease in the $\mathrm{CBB}$ population due to the presence of infected $\mathrm{CBB}$ by a mixture of B. bassiana strains. The infected CBBs failed to proliferate in coffee berries. The other biocontrol agents, i.e., Cephalonomia stephanotis Betrem (Hymenoptera: Bethylidae) and Phymastichus coffea LaSalle (Hymenoptera: Eulophidae), were also reported as two types the ants as parasitoids of CBBs $[19,20]$.

The soil fungus $B$. bassiana is widely known as an entomopathogenic fungus against a large number of insect species worldwide. However, the activity of $B$. bassiana is not entirely satisfactory due to its use in large quantities under field conditions. This fungus also needs to mix with other strains or natural compounds to be effectively used as a biological control agent against CBBs [21, 22]. The uses of two types of ants as parasitoids are not always available against the larvae and pupae of the CBBs. Their availability is highly dependent on their season to breed naturally, or they can only be produced on a limited scale for the proliferation of these two parasitoids to control CBBs population $[19,20]$. Thus, the uses of biological control agents require to be combined or mixed with natural insecticides (bioinsecticides) as an IPM to control more effectively and efficiently the CBBs $[15,16]$.

Nicotiana tabacum is well known as a natural insecticide to eradicate the insects. Previous studies reported that $N$. tabacum contains at least 200 hazardous chemicals, including nicotine, phenolic compounds, and diterpene [23-25]. They are the compounds that are mostly found in tobacco leaves. Nevertheless, the composition of N. tabacum extract can potentially change depending on the species, place of origin, type of extraction methods, and solvents used [25]. Nicotine, phenolic compounds, and diterpene are toxic to insects, especially for nicotine that acts as a neurotoxin for most pest insects, mammals, and birds [26, 27]. On the other hand, the extract of Nicotiana tabacum could reduce the protein content of both coffee bean and skin which is used by CBBs for their growth and development, thus lowering the risk of insect pests [28].

The previous studies reported that $N$. tabacum extract had been used to eradicate and prevent most insects and other pests. The combination of $320 \mathrm{~g}$ Beauveria bassianal $8 \mathrm{~L}$ of water and $30 \mathrm{~mL}$ Nicotiana tabacum extract/10 L of water was found to be able to reduce the percentage and intensity of coffee fruit attacked by CBB to $1.54 \%$ and $0.33 \%$, respectively [29]. The attack of cabbage looper (Trichoplusia binotalis), as the significant insects under field conditions in cabbage plantation, was also significantly lower with an application of 3\% aqueous extract of N. tabacum. The cabbage looper attack was only $9.32 \%$ that occurred on the field, while the attack to the control was $34.23 \%$ [30]. Other previous studies also reported that Nicotiana tabacum $L$. leaf extract obtained from Ethanolic Heat Reflux Extraction (EHRE) had shown insecticidal activity against some agricultural pests such as Gryllus bimaculatus (cricket), Galleria mellonella (greater wax moth) larvae, Tenebrio molitor (mealworm beetle) larvae, and Zophobas morio (darkling beetle) larvae at $\mathrm{LC}_{50}$ values of $38.5 \mathrm{mg} / \mathrm{ml}, 36.6 \mathrm{mg} / \mathrm{ml}, 21.1 \mathrm{mg} / \mathrm{ml}$, and $71.1 \mathrm{mg} / \mathrm{ml}$, respectively [31, 32]. The top fraction bio-oil of $N$. tabacum was also reported as a biorepellent to protect human skin from mosquito bites. The result showed that the average percentage of human skin protection against mosquito bites was $57.07 \%$ for 6 hours, using 3\% bio-oil concentration [24].

This study focuses on the investigation of the ethanolic heat reflux extract of the Nicotiana tabacum (EHRE-Nt) to control the intensity of CBBs attack. The main novelty of this study is the application of the EHRE-Nt as a bioinsecticide against a major pest insect of Hypothenemus hampei Ferrari (Coleoptera: Scolytidae) on Robusta coffee plantation. This study examined the intensity of CBBs attack expressed in percentages of damaged coffee berries. The efficacy level of EHRE-Nt formulation on CBBs attack was also calculated. 


\section{Materials and Methods}

2.1. Materials. The ethanolic heat reflux extract of N. tabacum L. var Virginia (EHRE-Nt), Hypothenemus hampei Ferrari (Coleoptera: Scolytidae), and the coffee berries on Robusta coffee plantation were used in this study. Dichlorodiphenyltrichloroethane, organophosphorus pesticides mix, and carbamate standards used for thin-layer chromatography (TLC) analysis were purchased from Sigma-Aldrich, Germany. Silica gel 60G $\mathrm{F}_{254}$ TLC plates were also purchased from Merck Co., Germany.

2.2. Biopesticide Preparation. Tobacco leaves were taken from Ponorogo District (East Java, Indonesia). The procedure for obtaining a high yield of EHRE-Nt was explained in the previous study [23]. Ethanolic heat reflux extraction was used for our previous study to produce EHRE-Nt. The extraction was achieved at 6 hours to obtain a high yield of EHRE-Nt with the optimum temperature at $70^{\circ} \mathrm{C}, 150 \mathrm{rpm}$, and a fixed solid-to-solvent ratio at $1: 5$.

An amount of $150 \mathrm{ml}, 300 \mathrm{ml}$, and $450 \mathrm{ml}$ of the concentrated EHRE-Nt was added to three stainless steel containers containing each $100 \mathrm{l}$ of water. They were named as E1, E2, and E3, respectively. These formulations were sprayed on the coffee plantation. A nontreatment of coffee beans was applied as a control, named as C.

2.3. Location of Efficacy Assay. The coffee plantation is located in the Kalibening area, Kebondalem Village, in Jambu district (South Semarang, Central Java, Indonesia). The coordinate of the area is $7^{\circ} 16^{\prime} 44^{\prime \prime} \mathrm{S}$ and $110^{\circ} 20^{\prime} 11^{\prime \prime} \mathrm{E}$, with an altitude of $650-710 \mathrm{~m}$ above sea level (m.a.s.l.), an average temperature of $18.6^{\circ} \mathrm{C}$, and an average annual rainfall of $2801 \mathrm{~mm}$ [33]. Kalibening is surrounded by four mountains, i.e., Ungaran, Merbabu, Sumbing, and Sindoro (see Figure 1). Thus, the climate and soil conditions in this area are suitable for Robusta coffee production. There were a total of 2 hectares that are used for this experiment, i.e., 1.5 hectares for the field assays and 0.5 hectares for the control. The experiments were carried out for six weeks.

2.4. Characterization of the Extract. Characterization of chemical compounds in the EHRE-Nt was conducted by a GC-MS from Agilent Technologies 7890 Series with autosampler, 5975 Mass Selective Detector, and Chemstation Data System. An electron impact using ionization mode with $70 \mathrm{eV}$ of electron energy was set for this instrument. The samples of EHRE-Nt were injected into a capillary column HP Ultra 2L with $30 \times 0.25 \mathrm{~mm}$ ID and $0.25 \mu \mathrm{m}$ film thicknesses. The GC-MS analysis was conducted at the Regional Health Laboratory (Labkesda), Jakarta.

The presence of any residual of organochlorine, organophosphate, and carbamate was characterized using thin-layer chromatography (TLC) with methyl alcohol p.a as a mobile phase. These TLC assays were conducted at the Bureau of Testing and Certifications for Quality of Commodities, Agency for the Industrial and Commercial Affairs,
Central Java Provincial Government, Republic of Indonesia. Silica gel 60G $\mathrm{F}_{254}$ TLC plates (Merck Co., Germany) were used as the stationary phase. The residues of $\mathrm{As}, \mathrm{Pb}, \mathrm{Cd}$, and $\mathrm{Hg}$ were also analyzed by the atomic absorption spectroscopy (AAS) method. These assays were conducted at Laboratory for Testing Quality of Medicinal, Food and Cosmetical, Faculty of Pharmacy, Universitas Indonesia. A hydride vapor generation (HVG) was used as a flame selection of AAS for Arsenic (As) detection, while for $\mathrm{Pb}$ and $\mathrm{Cd}, \mathrm{O}_{2}-\mathrm{C}_{2} \mathrm{H}_{2}$ was used as a flame of AAS. A flame of Mercury vapor unit (MVU) was then used for $\mathrm{Hg}$ detection by AAS.

2.5. Randomized Block Design (RBD). RBD by triplicate was used as a model for this experiment. Three blocks of coffee plants were used for the assays (Block I-III). A block was used for control (Block IV). Each block consists of three replications of each extract solution in randomized three sample coffee plants on 0.5 hectares. The model of RBD is presented in Table 1 . They were observed for six weeks on the coffee plantation.

2.6. The Intensity of CBBs Attack and Efficacy EHRE-Nt as a Bioinsecticide. The intensity of CBBs attacks (I) was calculated using the formula shown in equation (1), where $x$ and $y$ are the numbers of damaged coffee berries due to CBBs attack and amount of nondamaged coffee berries, respectively:

$$
I=\frac{x}{(x+y)} \cdot 100 \%
$$

The efficacy criteria of bioinsecticide using EHRE-Nt can be calculated based on the number of coffee berries attacked on the coffee plantation. Observation of coffee berries damage due to CBBs before application of EHRE-Nt showed no significant difference between treatment blocks. Therefore, the efficacy level $(E)$ of the extract formulation can be calculated using the Abbot formula shown in equation (2) below with $\mathrm{Ca}$ and $\mathrm{Ta}$ as the intensity of CBBs attack to the control block after application of the EHRE-Nt (\%) and intensity of CBBs attack to treatment block after application of the EHRE-Nt (\%) respectively:

$$
E=\frac{\mathrm{Ca}-\mathrm{Ta}}{\mathrm{Ca}} \cdot 100 \% .
$$

The EHRE-Nt formulation was effectively used as bioinsecticide to prevent CBBs attack on coffee plants if the efficacy level of the extract formulation is greater than $50 \%$ $[14,34]$.

2.7. Morphology of Coffee Bean by Scanning Electron Microscopy (SEM). SEM (JSM-6510 LA, JEOL Ltd., Japan) was used to compare the morphological differences between coffee bean samples, which were infected and uninfected by CBBs. This morphological comparison is intended to see the impact of damage on coffee beans due to CBB attacks on a microscale. The coffee bean samples (infected and 


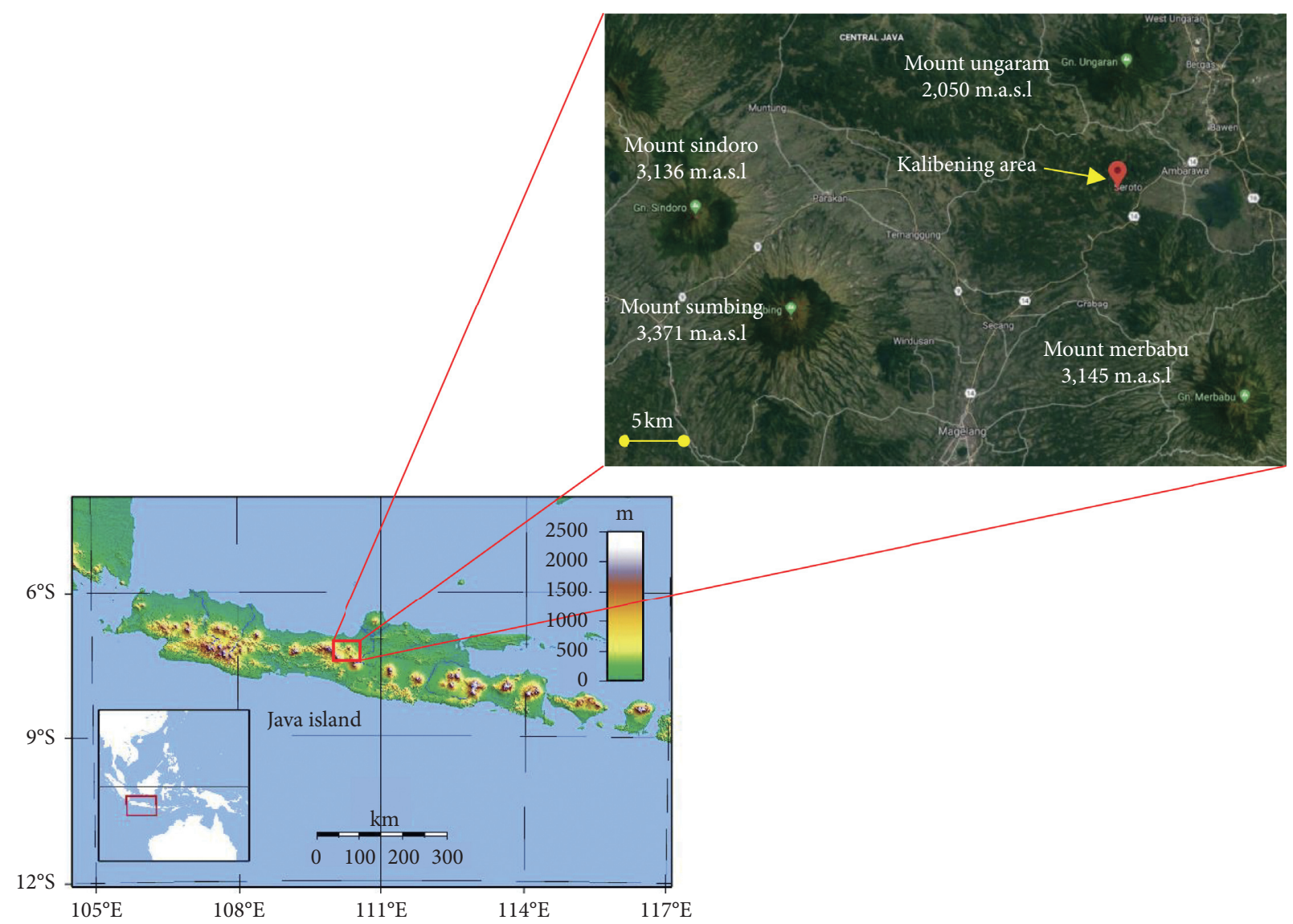

Figure 1: Geographic location of the Kalibening area (a robusta coffee plantation). This location is surrounded by four mountains, i.e., Ungaran, Merbabu, Sumbing, and Sindoro. Kalibening is located at Kebondalem village, Jambu district, South Semarang, Central Java, Indonesia (source: modified from Google Maps).

TABLE 1: The triplicated randomized block design (RBD) in this experimental design.

\begin{tabular}{lcc}
\hline Block (@area $=0.5$ hectare $)$ & Extract $^{\dagger}(\mathrm{ml})$ & Sample name $^{\ddagger}$ \\
\hline \multirow{2}{*}{ I } & 150 & E1-T01 \\
& 150 & E1-T02 \\
& 150 & E1-T03 \\
\hline \multirow{2}{*}{ II } & 300 & E2-T04 \\
& 300 & E2-T05 \\
\hline \multirow{3}{*}{ III } & 300 & E2-T06 \\
& 450 & E3-T07 \\
& 450 & E3-T08 \\
Control & 450 & E3-T09 \\
& 0 & C-T10 \\
\end{tabular}

${ }^{\dagger}$ Each extract was diluted into 1001 of water, except the control. ${ }^{\ddagger} \mathrm{E} 1, \mathrm{E} 2$, and E3 are the extract solutions that consist of 150,300 , and $450 \mathrm{ml}$ of the concentrated extract, respectively. They are then sprayed into the randomized plants on a total of 2 hectares. T01 until T12 are the randomized coffee plants used in this study. $\mathrm{C}$ is the control without treatment.

uninfected) were coated with gold under vacuum conditions. The accelerated voltages and samples diameter observed were $15 \mathrm{kV}$ and ten $\mu \mathrm{m}$, with $1000 \mathrm{X}$ magnification. The observation was carried out at around the cross section of both samples of coffee beans. The SEM analysis was performed at Sentra Teknologi Polimer, Agency for the Assessment and Application of Technology (BPPT).

\section{Results and Discussion}

3.1. Characteristics of the Extract. The characterization of chemical compounds in the EHRE-Nt by GC-MS analysis was carried out using Chemstation Databases System. The results are shown in Table 2.

The GC-MS result showed the presence of 16 different chemical compounds (see Table 2). There are two major chemical compounds in the extract, i.e., nicotine and linoleic acid. The contents of nicotine and linoleic acid obtained by GC-MS analysis were $6.30 \%$ and $3.72 \%$, in which these two contents larger than the other compounds. These results are similar to those found in other studies [35-38]. The nicotine content of Nicotiana tabacum L. leaves extract obtained from Heat Reflux Extraction (HRE) technique at 6 hours was found to be $6.3 \%$ by HPLC [35]. Huang et al. [38] found that another compound with a percent of relative content more than $20 \%$, i.e., androsta-3,5-dien-7-one (21.06\%), which are not found in our result [38]. However, GC-MS results of the nicotine compound obtained in Shen and Shao [37]; Hossain and Salehuddin [36]; and also Huang et al. [38] were 
TABle 2: The GC-MS ${ }^{\dagger}$ spectral analysis of EHRE-Nt ${ }^{\ddagger}$.

\begin{tabular}{|c|c|c|c|c|c|}
\hline No. & $\mathrm{RT}^{\S}(\min )$ & Name of the compound & Molecular formula & Molecular weight & Peak area $(\%)$ \\
\hline 1 & 12.76 & Nicotine & $\mathrm{C}_{10} \mathrm{H}_{14} \mathrm{~N}_{2}$ & 162 & 49.18 \\
\hline 2 & 28.21 & Hexadecanoic acid, methyl ester & $\mathrm{C}_{17} \mathrm{H}_{34} \mathrm{O}_{2}$ & 270 & 1.80 \\
\hline 3 & 28.66 & Hexadecanoid acid (Palmitic acid) & $\mathrm{C}_{16} \mathrm{H}_{32} \mathrm{O}_{2}$ & 256 & 2.01 \\
\hline 4 & 28.73 & Hexadecanoic acid, ethyl ester & $\mathrm{y}^{\prime} \mathrm{C}_{18} \mathrm{H}_{36} \mathrm{O}_{2}$ & 284 & 2.06 \\
\hline 5 & 29.14 & Methyl 10-trans,12-cis-octadecadienoate & $\mathrm{C}_{19} \mathrm{H}_{34} \mathrm{O}_{2}$ & 294 & 0.62 \\
\hline 6 & 29.19 & 11-Octadecanoic acid, methyl ester & $\mathrm{C}_{19} \mathrm{H}_{36} \mathrm{O}_{2}$ & 296 & 2.43 \\
\hline 7 & 29.38 & Methyl 9-cis,11-trans-octadecadienoate & $\mathrm{C}_{19} \mathrm{H}_{34} \mathrm{O}_{2}$ & 294 & 0.72 \\
\hline 8 & 29.41 & Methyl 9-Octadecenoate & $\mathrm{C}_{19} \mathrm{H}_{36} \mathrm{O}_{2}$ & 296 & 2.64 \\
\hline 9 & 29.56 & Methyl stearate & $\mathrm{C}_{19} \mathrm{H}_{38} \mathrm{O}_{2}$ & 298 & 0.47 \\
\hline 10 & 29.76 & 9,12-Octadecadienoic acid (Linoleic acid) & $\mathrm{C}_{18} \mathrm{H}_{32} \mathrm{O}_{2}$ & 280 & 29.01 \\
\hline 11 & 31.46 & Methyl 20-methyl-heneicosanoate & $\mathrm{C}_{23} \mathrm{H}_{46} \mathrm{O}_{2}$ & 354 & 0.91 \\
\hline 12 & 31.63 & 13-Docosenoic acid & $\mathrm{C}_{22} \mathrm{H}_{42} \mathrm{O}_{2}$ & 338 & 1.86 \\
\hline 13 & 31.77 & Ethyl pentadecanoate & $\mathrm{C}_{17} \mathrm{H}_{34} \mathrm{O}_{2}$ & 270 & 0.53 \\
\hline 14 & 32.73 & 15-Tetracosenoic acid, methyl ester & $\mathrm{C}_{25} \mathrm{H}_{48} \mathrm{O}_{2}$ & 380 & 1.89 \\
\hline 15 & 34.14 & 22-Tricosenoic acid & $\mathrm{C}_{23} \mathrm{H}_{44} \mathrm{O}_{2}$ & 352 & 1.91 \\
\hline 16 & 35.72 & Stigmastan-3,5-diene & $\mathrm{C}_{29} \mathrm{H}_{48}$ & 396 & 1.96 \\
\hline
\end{tabular}

${ }^{\dagger}$ Gas chromatography-mass spectrometry analysis was conducted at the regional health laboratory (Labkesda), special capital region (DKI) of Jakarta. No.: 2.3/1582. ${ }^{*}$ The ethanolic heat reflux extract of N. tabacum L. var Virginia origin of Ponorogo. ${ }^{S}$ Retention time for each detected compound expressed in minutes.

detected less than our GC-MS result, i.e., 2.90\%, 3.60\%, and $4.25 \%$, respectively [36-38]. On the contrary, we found the substance of linoleic acid, which is not found in Huang et al. [38]. In most cases, the nicotine is the predominant compound in Nicotiana tabacum and Nicotiana rustica, with the range $0.5-8 \%[25,39]$.

The mass-spectral chromatograms and chemical structures of nicotine and linoleic acid in the EHRE-Nt are shown in Figures 2 and 3. The presence of nicotine and linoleic acid compounds was proven by the pattern of fragmentations that occurred in each mass-spectral chromatograms (see Figures 3 and 4). The patterns of fragmentation of these two compounds were similar to the standard of nicotine and linoleic acid obtained from the Chemstation Databases System. A molecular ion peak $\left(\mathrm{M}^{+}\right)$of nicotine was achieved at $m / z 161.1$, while linoleic acid has $\mathrm{M}^{+}$at $m / z 280.3$. These molecular ion peaks were $97 \%$ and $99 \%$ similar to the molecular weight of nicotine and linoleic acid standards, i.e., 162 and $280 \mathrm{~g} / \mathrm{mol}$.

TLC qualitatively characterized any residuals of organochlorine, organophosphate, and carbamate as hazardous chemicals that could be found in the EHRE-Nt. AAS methods also examined any residual substances of $\mathrm{As}, \mathrm{Pb}$, $\mathrm{Cd}$, and $\mathrm{Hg}$. Seven types of hazardous components were examined to the EHRE-Nt (see Table 3). The results showed that there were no hazardous residues in the extract except a tiny amount of Arsenic (As) substance. It was $<1 \mu \mathrm{g} / \mathrm{g}$ of extract (under the limit of $1 \mu \mathrm{g} / \mathrm{g}$ as an allowable limit). Thus, the EHRE-Nt would not be harmful if it is exposed to the plants as a natural insecticide nor contacted with human skin.

3.2. The Intensity of CBBs Attack. The intensity of CBBs attack on coffee berries is shown in Figures 4-6. Figure 4 shows the coffee berry with infection by CBB and without. Figure 5 shows the CBBs and the impact of their attacks in a coffee berry. The morphological differences of damaged coffee bean samples due to CBBs attack and undamaged coffee bean as control were examined using scanning electron microscope (SEM) on a microscale. The results are shown in Figure 6.

The damaged coffee bean in a microscale due to the Hypothenemus hampei (CBBs) attack was shown in Figure 6(b). The coffee bean appears rough and visibly damaged morphological structures. This condition occurs due to the coffee bean that is consumed by the larvae and pupae of CBBs. They can consume coffee beans starting from the hole where they live in and spread until the whole of the coffee bean. So, if compared to the undamaged coffee bean as a control, then undamaged coffee bean tends to be more subtle than the damaged coffee bean (see Figures 6(a) and 6(b)). For immature coffee berries, this condition can damage endosperm cells. If the endosperm cells are broken, then coffee berries with the seeds inside become rotten and fall. For mature coffee berries, the damaged condition causes perforated coffee beans. The defective coffee beans also significantly affect the composition of their chemical compounds inside, especially at caffeine and reducing sugars. So, this condition affects the taste of the coffee and will degrade the quality of the coffee $[4,40]$.

The percentages of the intensity of CBBs attack to coffee berries on a coffee plantation in the block I-IV for six weeks of observation are shown in Figure 7. They were obtained based on the calculation result using (1).

Figure 7 shows that the lowest intensity of CBBs attack was achieved by formula E3 (450 ml EHRE-Nt in 1001 water), i.e., $1.5 \pm 0.10 \%$. This value was achieved at the $3^{\text {rd }}$ week observation. The highest intensity of CBBs attack was achieved by formula E1 (150 ml EHRE-Nt in 1001 water), i.e., $6.0 \pm 0.25 \%$. It was reached at the $4^{\text {th }}$-week observation, while the range of $\mathrm{C}$ or control (without treatment) to the intensity of $\mathrm{CBBs}$ attack that occurs was between $11.3 \pm 0.28 \%$ and $13.5 \pm 0.50 \%$. They were achieved at the $1^{\text {st }}$ to $6^{\text {th }}$ week's observation. Thus, the average intensity of CBBs attack of $C, E 1, E 2$, and E3 formulas was $12.6 \%, 4.3 \%$, 


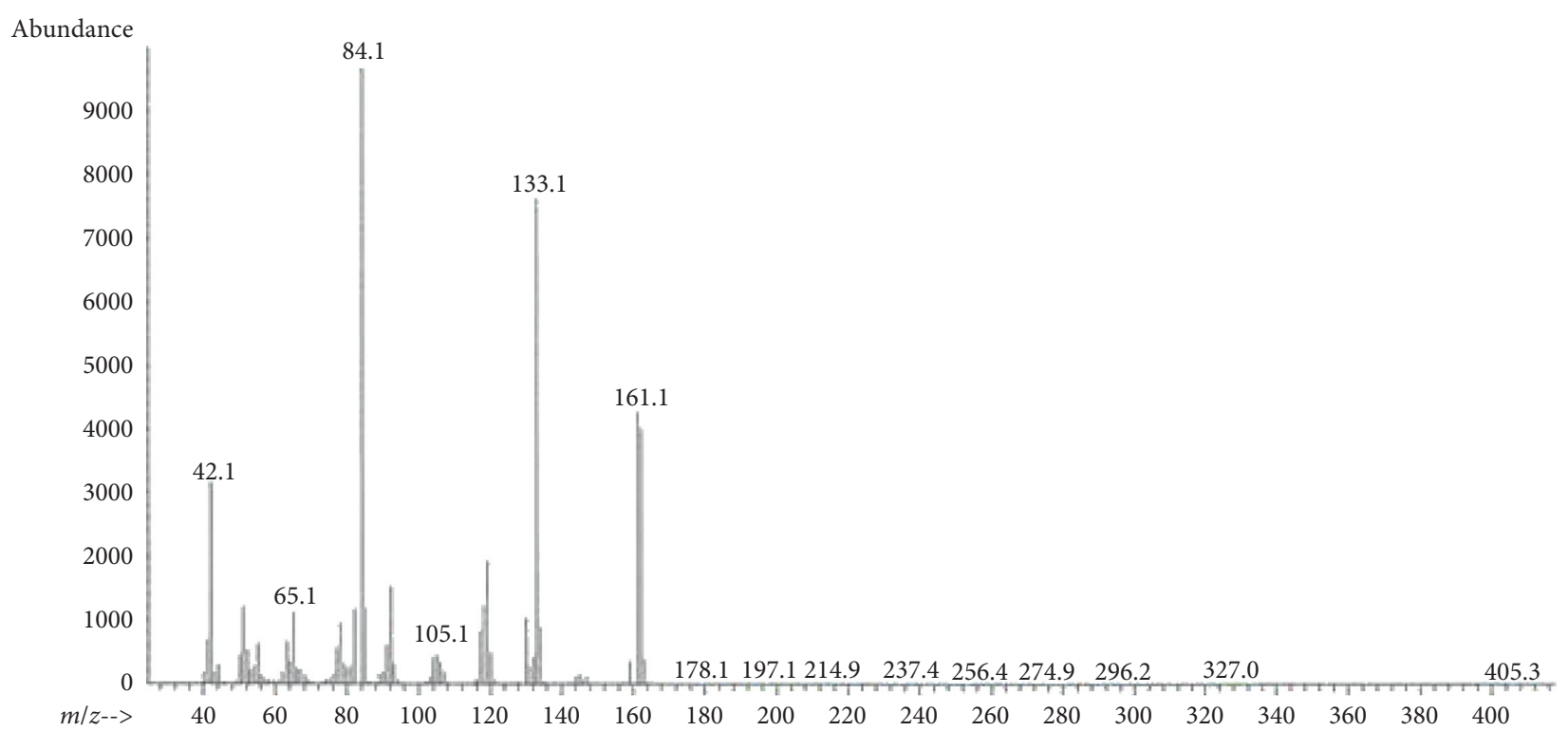

(a)

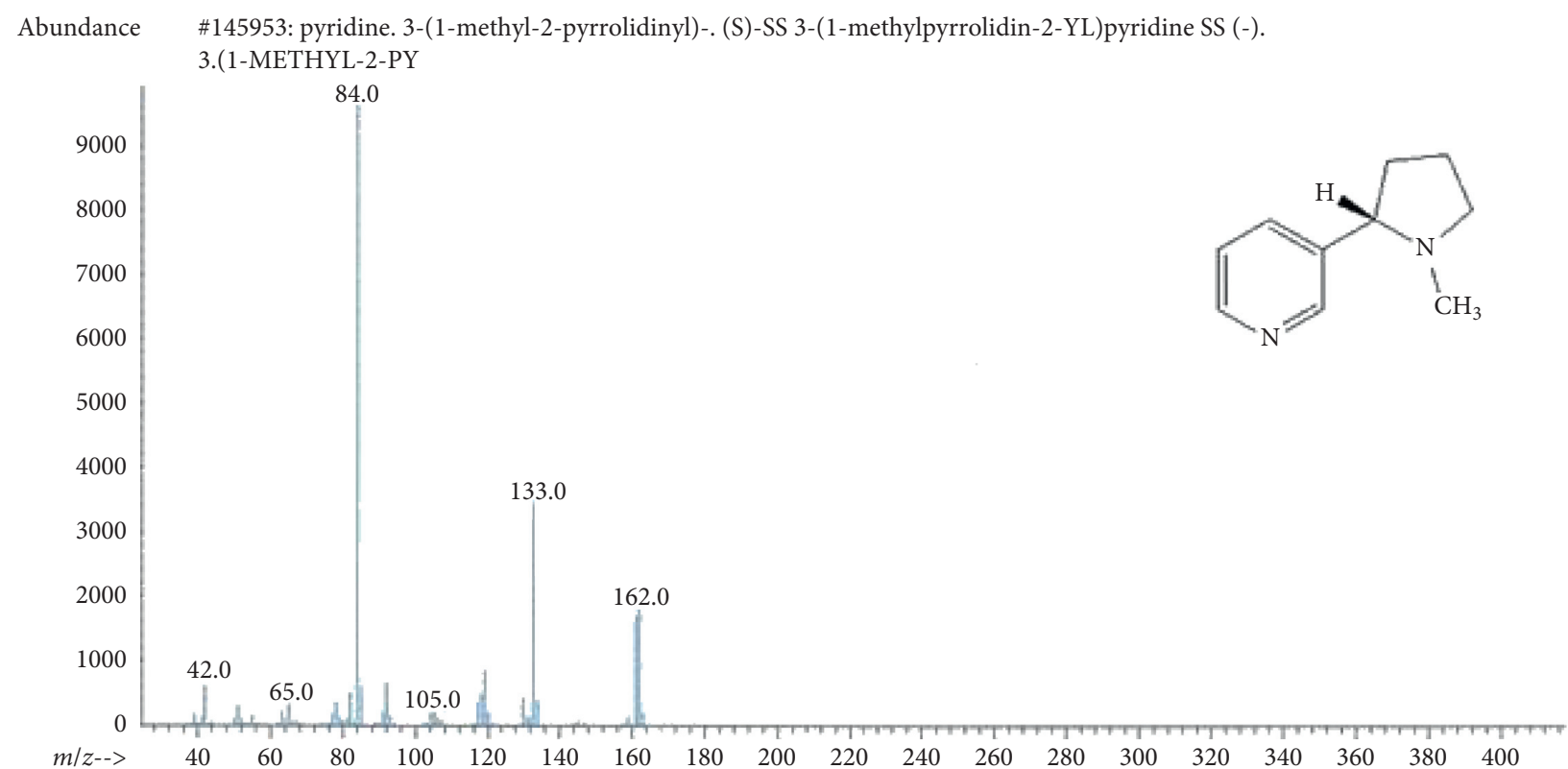

(b)

Figure 2: The mass-spectral chromatogram of nicotine in the ethanolic heat reflux extract of N. tabacum L. var Virginia origin of Ponorogo (a) and the nicotine standard (b).

$3.1 \%$, and $1.8 \%$. These results expressed that all applications of three extract formulations of E1, E2, and E3 showed a significantly lower intensity of CBBs attack to coffee berries on the coffee plantation than the control.

The efficacy level of EHRE-Nt as a bioinsecticide against CBBs attack was then calculated using (2). They were obtained based on the average percentages of the intensity of CBBs attack. The results are shown in Table 4 above.

The highest efficacy level of EHRE-Nt formulation as bioinsecticide against the Hypothenemus hampei (CBBs) attack was achieved by E3 formulation; it was $85.4 \%$. The lowest efficacy level of the extract formulation as a bioinsecticide was achieved by E1 formulation; it was $66.1 \%$. However, the overall percent values of the efficacy level of the extract formulations as a bioinsecticide were higher than $50 \%$ as a minimum value for bioinsecticide effectiveness (see Table 4). Thus, the EHRE-Nt has a high efficacy as a bioinsecticide to protect coffee berries on a coffee plantation against CBBs attack. Furthermore, EHRE-Nt had the lowest intensity of CBB attacks $(1.5 \pm 0.1 \%)$ and even the lowest extract concentration ( $4.5 \mathrm{ml} / \mathrm{l}$ water) if 


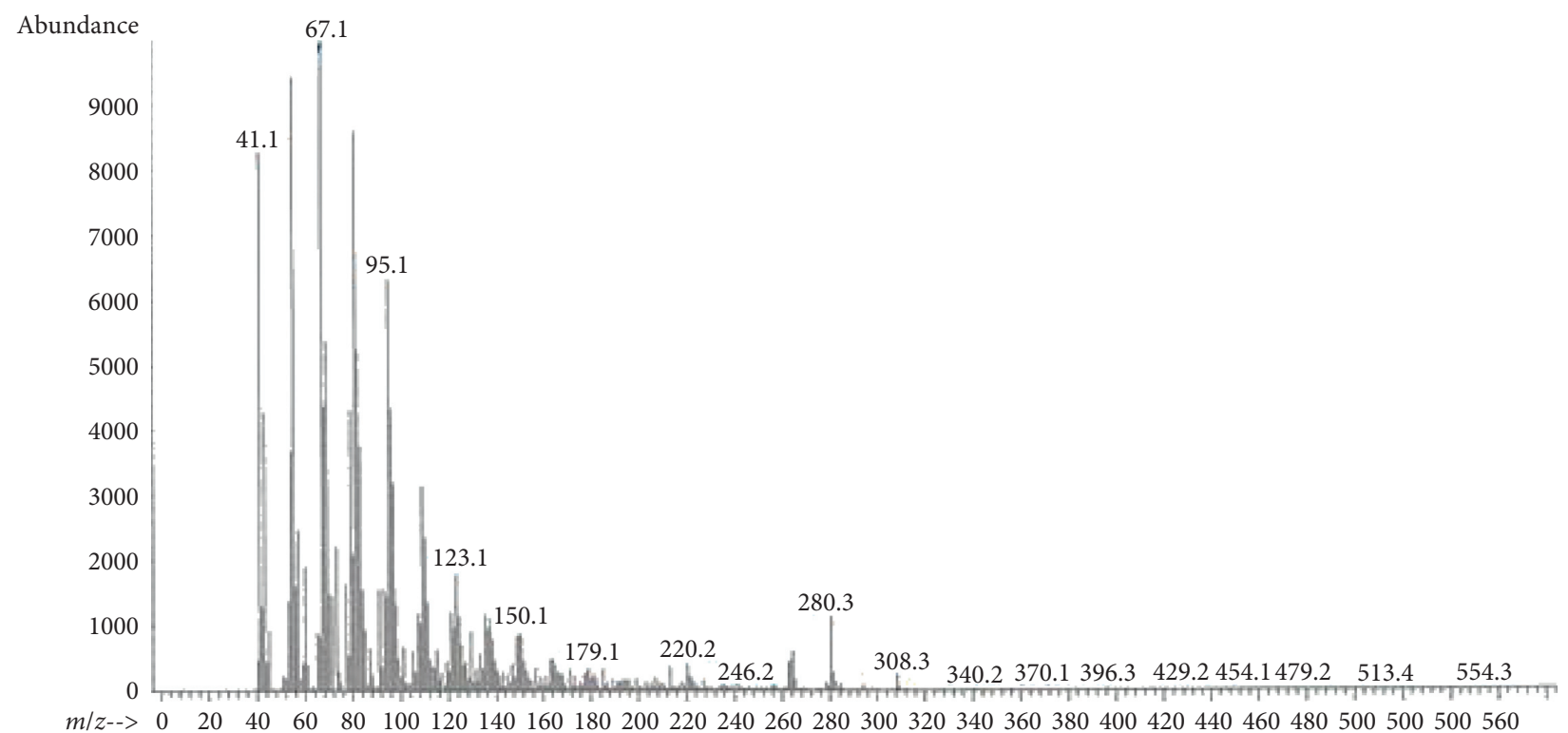

(a)

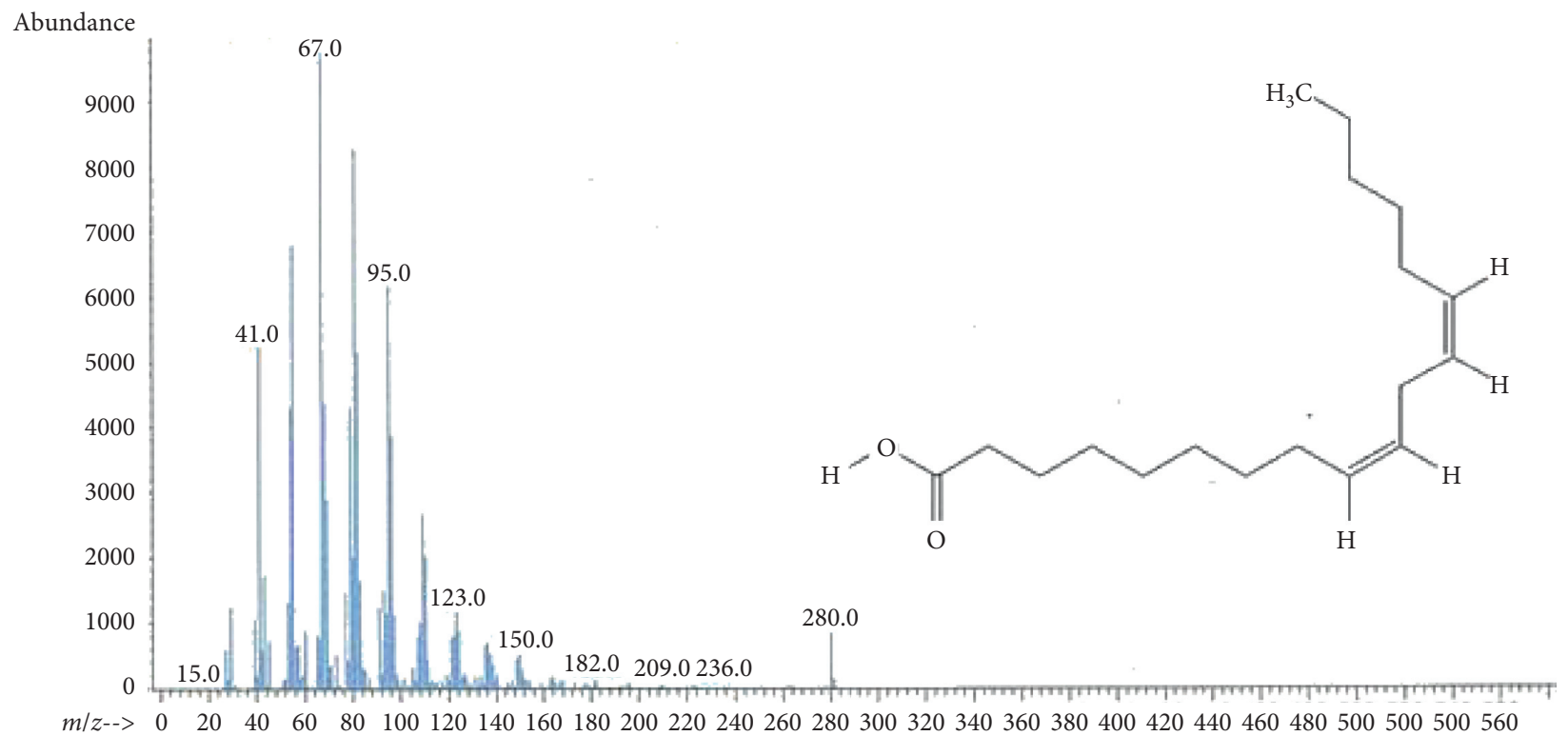

(b)

Figure 3: The mass-spectral chromatogram of linoleic acid in the ethanolic heat reflux extract of N. tabacum L. var Virginia origin of Ponorogo (a) and the linoleic acid standard (b).

compared with the result of other previous studies as can be seen in Table 5. This showed that EHRE-Nt is effective to be used as a prospective bioinsecticide against $\mathrm{CBB}$ at low extract concentration.

This study shows that the highest efficacy level of EHRE-Nt was achieved by E3 formulation of $450 \mathrm{~mL}$ EHRE-Nt in $100 \mathrm{~L}$ water or equals to $0.45 \%$ in terms of concentration. The result of GC-MS spectral analysis also indicated that the nicotine content of EHRE-Nt was not more than 50\%, which further means that the actual concentration of nicotine in E3 formulation was only about $0.23 \%$. This value is far below the lower limit of ingested nicotine, causing a fatal outcome of $0.5-1 \mathrm{~g}$ corresponding to an oral $\mathrm{LD}_{50}$ of $6.5-13 \mathrm{mg} / \mathrm{kg}$ $(0.65-1.3 \%)[43,44]$. Furthermore, nicotine was assigned as a botanical insecticide with dissipation half-live of 2.51 days, thus making it readily dissipated from treated plants [45]. In addition, acute oral toxicity test showed that $5 \mathrm{~g}$ Nicotiana Tabacum L. bio-oil, with nicotine as the most dominant compound, per kg body weight of female Wistar rats was not toxic due to the absence of mortality and no significant change of the body weight and behavior of the rats [46]. It could be concluded that besides its far below toxicity level to humans and animals, the EHRE-Nt shows highly potential bioinsecticidal activity. 


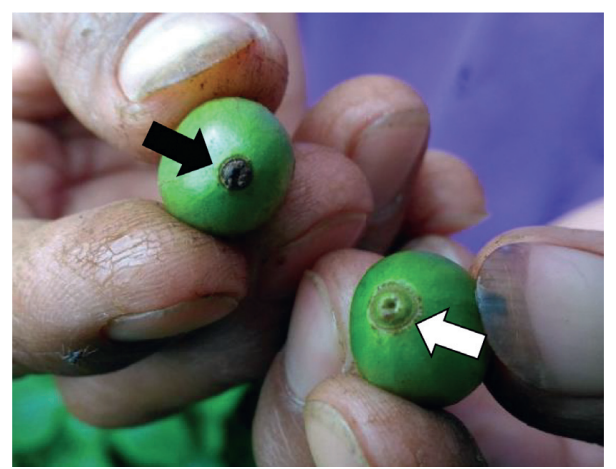

FIGURE 4: Field sampling to coffee berries show a half-mature coffee berry that is infected by the CBB (black arrow) and uninfected by the CBB (white arrow). An infected coffee berry indicated by the presence of a black-hole on the surface of a coffee berry.

TABLE 3: Residual assay of EHRE-Nt ${ }^{\dagger}$.

\begin{tabular}{lcc}
\hline Hazardous chemicals & Results & Methods \\
\hline (1) Organochlorine & Negative & TLC $^{\ddagger}$ \\
(2) Organophosphate & Negative & TLC \\
(3) Carbamate & Negative & TLC \\
(4) Arsenic (As) & $<1 \mu$ g/g & AAS-HVG $^{\S}$ \\
(5) Pb & Negative & AAS-O $_{2}-\mathrm{C}_{2} \mathrm{H}_{2}$ \\
(6) Cadmium (Cd) & Negative & AAS-O $_{2}-\mathrm{C}_{2} \mathrm{H}_{2}$ \\
(7) $\mathrm{Hg}$ & Negative & AAS-MVU $^{\perp}$ \\
\hline
\end{tabular}

${ }^{\dagger}$ The ethanolic heat reflux extract of N. tabacum L. var Virginia origin of Ponorogo. ${ }^{*}$ Thin-layer chromatography. ${ }^{\S}$ Atomic absorption spectroscopy-hydride vapour generation. ${ }^{\perp}$ Atomic absorption spectroscopy-mercury vapour unit.

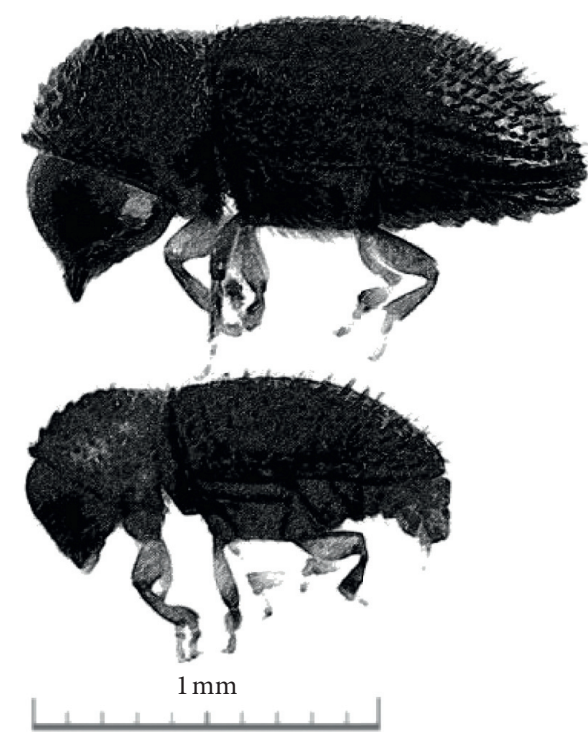

(a)

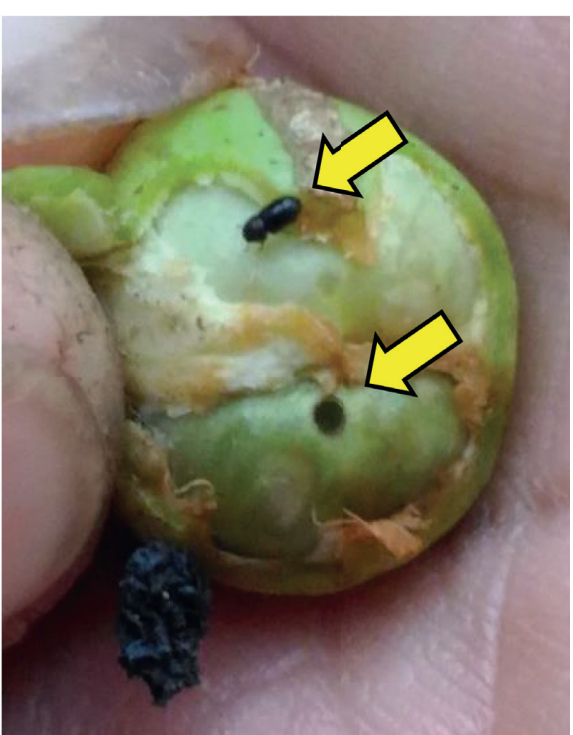

(b)

FIgURE 5: Continued. 


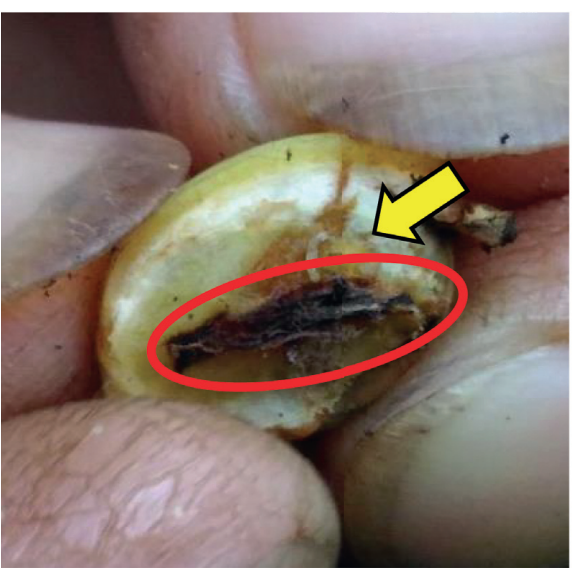

(c)

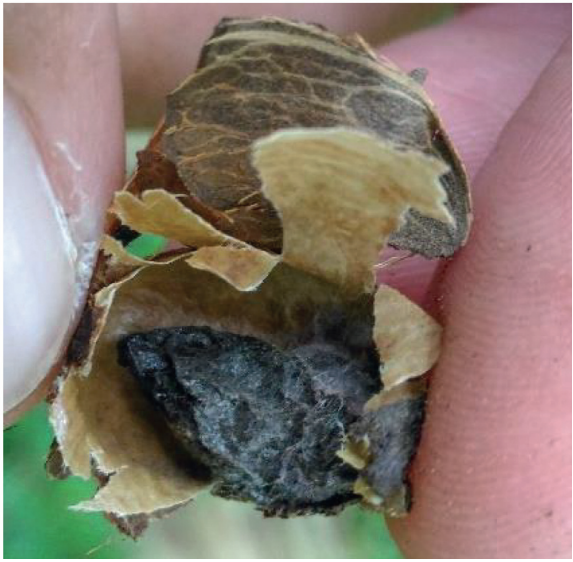

(d)

Figure 5: (a) Lateral view of female (top) and male (down) of CBBs (H. hampei). Field samplings show (b) dorsal view of female CBB (upper arrow), a hole (lower arrow) appeared in a coffee berry. (c) A half-mature coffee berry with cross section of the hole (circled) with larvae of CBB (arrow) appears in the picture. (d) A rotten coffee berry infected by CBB.



(a)

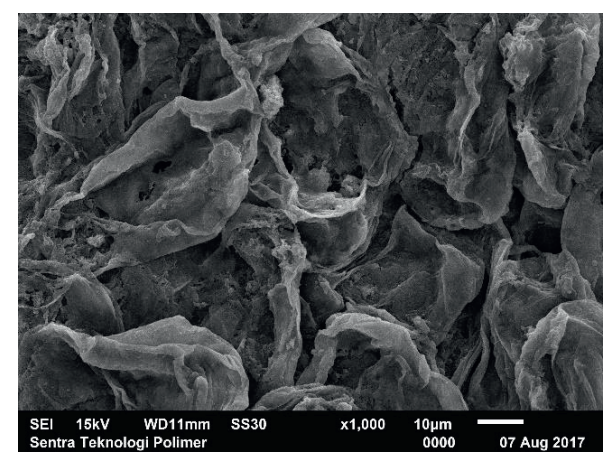

(b)

FIgURE 6: Scanning electron micrograph of a cross section coffee bean both in microscales with 1000X magnification. (a) An uninfected coffee bean as a control. (b) An infected coffee bean by CBB.

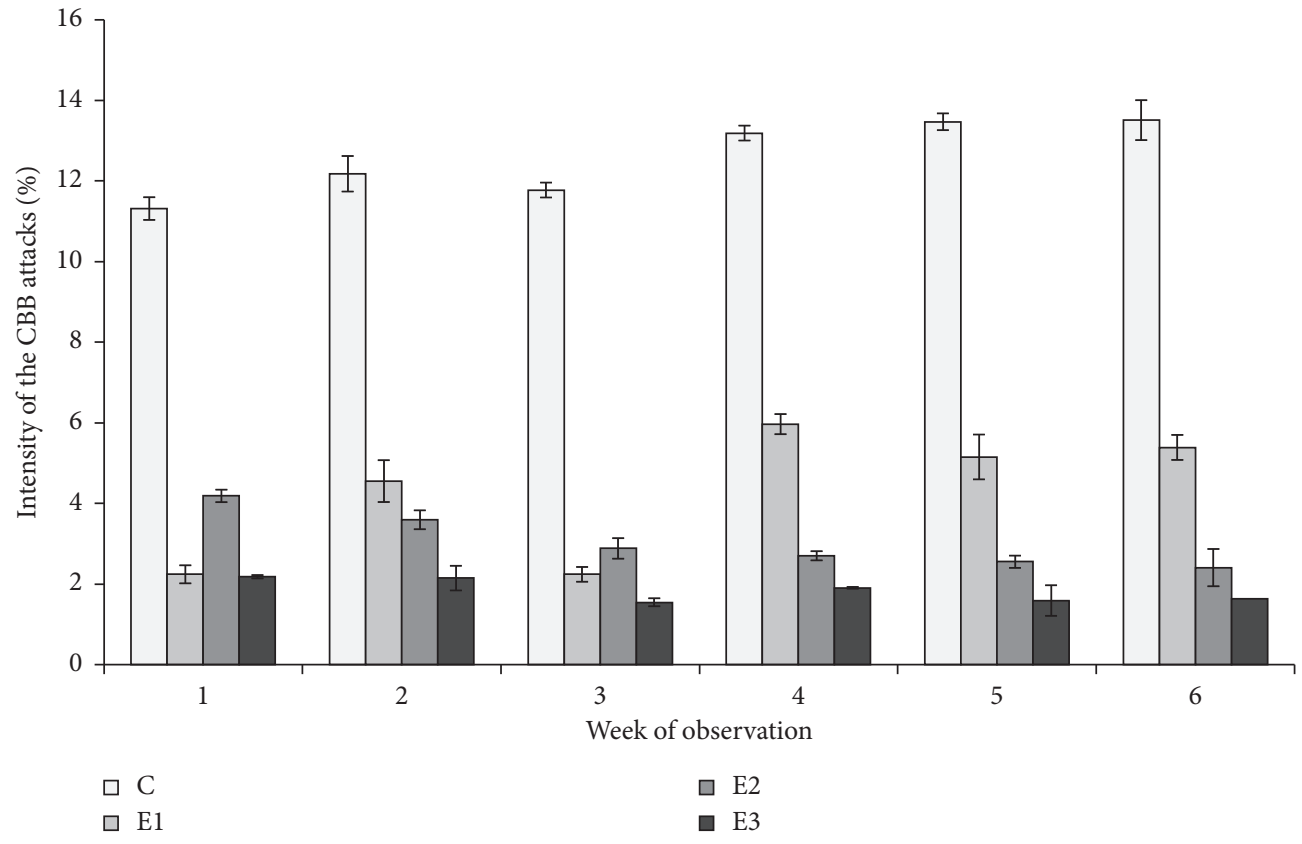

Figure 7: The percentage of intensity of the CBB attacks during six weeks of observation (mean $\pm \mathrm{SD} ; n=3$ ). C is the control. E1, E2, and E3 are $150 \mathrm{ml}, 300 \mathrm{ml}$, and $450 \mathrm{ml}$ of the ethanolic heat reflux extract of $\mathrm{N}$. tabacum L. var Virginia origin of Ponorogo (EHRE-Nt), each diluted with 1001 of water. 
TABLE 4: The efficacy level of EHRE-Nt ${ }^{\dagger}$ against coffee borer beetle attacks.

\begin{tabular}{lr}
\hline $\mathrm{EHRE}^{-\mathrm{Nt}^{\dagger}}$ formulation & Efficacy level as a bioinsecticide (\%) \\
\hline $\mathrm{E}^{\ddagger}$ & 66.14 \\
$\mathrm{E}^{\S}$ & 75.71 \\
$\mathrm{E}^{\perp}$ & 85.42 \\
\hline
\end{tabular}

${ }^{\dagger}$ The ethanolic heat reflux extract of N. tabacum L. var Virginia origin of Ponorogo. ${ }^{*} 150 \mathrm{ml}$ EHRE-Nt in 1001 of water. ${ }^{\S} 300 \mathrm{ml}$ EHRE-Nt in 1001 of water.

${ }^{\perp} 450 \mathrm{ml}$ EHRE-Nt in 1001 of water.

TABle 5: Comparison of N. tabacum as a bioinsecticide against $\mathrm{CBB}^{\dagger}$ attacks on coffee plants.

\begin{tabular}{|c|c|c|c|}
\hline Bioinsecticide & $\begin{array}{l}\text { Concentration }^{*} \\
\text { (ml/l water) }\end{array}$ & $\begin{array}{l}\text { The intensity of the } \mathrm{CBB}^{\dagger} \text { attacks } \\
(\%)\end{array}$ & Reference \\
\hline $\begin{array}{l}\text { Volatile compounds of Nicotiana tabacum (companion } \\
\text { plant) }\end{array}$ & In the form of gas & $10.6 \pm 1.8$ & Castro et al. [41] \\
\hline Cassia spectabilis and Nicotiana tabacum $(1: 1)$ & 15.0 & $4.4 \pm 0.2$ & Wiryadiputra, [42] \\
\hline Nicotiana tabacum $\left(\right.$ EHRE- $\mathrm{Nt}^{\S}$ ) & 4.5 & $1.5 \pm 0.1$ & This study \\
\hline
\end{tabular}

\section{Conclusions}

The ethanolic heat reflux extract of N. tabacum L. var Virginia origin of Ponorogo (EHRE-Nt) has strong potential and is effectively used as a bioinsecticide against coffee borer beetle (Hypothenemus hampei) on the coffee plantation; it is concluded based on the results of this study that he EHRE-Nt can be quickly produced in a larger scale to supply the availability of the insecticide. A mixture of EHRE-Nt with other plant extracts, e.g., neem (Azadirachta indica) extract, as well as a combination of the EHRE-Nt with soil fungus B. bassiana or other natural predators against $H$. hampei on a coffee plantation, would very potentially be developed for further investigation. The results are expected to increase the efficacy level of bioinsecticide against coffee borer beetles. The use of EHRE-Nt also proves that the extract neither leaves any hazardous residue nor chemicals. So, it is safely used for the environment and is harmless if exposed to human skin.

\section{Nomenclature}

I: Intensity of CBBs attack (\%)

$x$ : Amount of damaged coffee berries due to CBBs attack

$y$ : Amount of nondamaged coffee berries

E: Efficacy level of the EHRE-Nt as a bioinsecticide (\%)

Ca: Intensity of CBBs attack to the control block after application of the EHRE-Nt (\%)

Ta: Intensity of CBBs attack to treatment block after application of the EHRE-Nt (\%)

E1: $150 \mathrm{ml}$ EHRE-Nt in 1001 water

E2: $300 \mathrm{ml}$ EHRE-Nt in 1001 water

E3: $450 \mathrm{ml}$ EHRE-Nt in 1001 water

C: Control without treatment.

\section{Data Availability}

The data used to support the findings of this study are available from the corresponding author upon request.

\section{Conflicts of Interest}

The authors declare that there are no conflicts of interest regarding the publication of this paper.

\section{Acknowledgments}

The authors are grateful for the financial support of the present study provided by the Publikasi Terindeks Internasional (PUTI KI) scheme for the budget year 2020 granted by Universitas Indonesia (NKB-784/UN2.RST/HKP.05.00/ 2020).

\section{References}

[1] J. R. Morris and I. Perfecto, "Testing the potential for ant predation of immature coffee berry borer (Hypothenemus hampei) life stages," Agriculture, Ecosystems \& Environment, vol. 233, pp. 224-228, 2016.

[2] D. D. Hendaryati and Y. Arianto, Tree Crop Estate Statistics of Indonesia 2015-2017: Coffee, Directorate General of Estate Crops Ministry of Agriculture, Jakarta, Indonesia, 2017.

[3] W. D. Silva, C. M. Costa, and J. M. S. Bento, "How old are colonizing Hypothenemus hampei (ferrari) females when they leave the native coffee fruit?" Journal of Insect Behavior, vol. 27, no. 6, pp. 729-735, 2014.

[4] F. Infante, J. Jaramillo, A. Castillo, and F. Vega, "The coffee berry borer, Hypothenemus hampei (ferrari) (coleoptera: curculionidae): a short review, with recent findings and future research directions," Terrestrial Arthropod Reviews, vol. 2, no. 2, pp. 129-147, 2009.

[5] F. E. Vega, F. Infante, R. W. Hofstetter, and A. J. Johnson, Bark Beetles: Biology and Ecology of Native and Invasive Species, Elsevier, Amsterdam, Netherlands, 2015.

[6] A. E. Pereira, E. F. Vilela, R. S. Tinoco et al., "Correlation between numbers captured and infestation levels of the coffee berry-borer, Hypothenemus hampei: a preliminary basis for an action threshold using baited traps," International Journal of Pest Management, vol. 58, no. 2, pp. 183-190, 2012. 
[7] J. Jaramillo, A. C. Olaye, C. Kamonjo et al., “Thermal tolerance of the coffee berry borer Hypothenemus hampei: predictions of climate change impact on a tropical insect pest," PLoS One, vol. 4, pp. 64-87, Article ID e6487, 2009.

[8] J. D. Rubio, A. E. Bustillo, L. F. Valelezo, J. R. Acuna, and P. Benavides, "Alimentary canal and reproductive tract of Hypothenemus hampei (ferrari) (coleoptera: curculionidae, scolytinae)," Neotropical Entomology, vol. 37, no. 2, pp. 143-151, 2008.

[9] J. Jaramillo and F. E. Vega, "Aphanogmussp. (hymenoptera: ceraphronidae): a hyperparasitoid of the coffee berry borer parasitoid Prorops nasuta (hymenoptera: bethylidae) in Kenya," Biocontrol Science and Technology, vol. 19, no. 1, pp. 113-116, 2009.

[10] C. Bass, A. M. Puinean, C. T. Zimmer et al., "The evolution of insecticide resistance in the peach potato aphid, Myzus persicae," Insect Biochemistry and Molecular Biology, vol. 51, pp. 41-51, 2014.

[11] A. S. Dehkordi, Y. S. Abadi, H. Nasirian et al., "Synergists action of piperonyl butoxide and S,S,S-tributyl phosphorotrithioate on toxicity of carbamate insecticides against Blattella germanica," Asian Pacific Journal of Tropical Medicine, vol. 10, pp. 981-986, 2017.

[12] S.-M. Dai, C. Chang, and X.-Y. Huang, "Distinct contributions of A314S and novel R667Q substitutions of acetylcholinesterase 1 to carbofuran resistance of chilo suppressalis walker," Pest Management Science, vol. 72, no. 7, pp. 1421-1426, 2015.

[13] Y. F. Chu, M. H. Yang, S. F. Chang, P. H Chen, and T. C. Wang, "The composition of life stages of coffee berry borer (Scolytidae: Hypothenemus hampei) in the coffee berry and the control efficacy of different insecticides for the pest," Journal of Taiwan Agricultural Research, vol. 66, pp. 318-325, 2017.

[14] D. Dent, Insect Pest Management, CABI Publication, Oxford, UK, 2000.

[15] L. F. Aristizábal, A. E. Bustillo, and S.P. Arthurs, "Integrated pest management of coffee berry borer: strategies from Latin America that could be useful for coffee farmers in Hawaii," Insects, vol. 7, no. 1, p. 6, 2016.

[16] G. Mawussi, A. K. Tounou, K. D. Ayisah et al., "Chemical composition and insecticidal activity of Ocimum canum essential oil against coffee berry Borer, Hypothenemus hampei (ferrari) (coleoptera: scolytidae)," Journal of Essential Oil Bearing Plants, vol. 15, no. 6, pp. 955-963, 2012.

[17] J. T. Vera, E. C. Montoya, P. Benavides, and C. E. Góngora, "Evaluation of Beauveria bassiana (ascomycota: hypocreales) as a control of the coffee berry borer Hypothenemus hampei (coleoptera: curculionidae: scolytinae) emerging from fallen, infested coffee berries on the ground," Biocontrol Science and Technology, vol. 21, no. 1, pp. 1-14, 2011.

[18] N. Haraprasad, S. R. Niranjana, H. S. Prakash, H. S. Shetty, and S. Wahab, "Beauveria bassiana-a potential mycopesticide for the efficient control of coffee berry borer, Hypothenemus hampei (ferrari) in India," Biocontrol Science and Technology, vol. 11, no. 2, pp. 251-260, 2001.

[19] A. Roobakkumar, S. D. Samuel, M. M. Balakrishnan, and K. Sreedharan, "Release and establishment of the parasitoid cephalonomia stephanoderis betrem against the coffee berry Borer Hypothenemus hampei ferrari in Pulney hills, Tamil Nadu, India," Entomological News, vol. 124, no. 3, pp. 221-223, 2014.

[20] J. C. Espinoza, F. Infante, A. Castillo et al., "The biology of Phymastichus coffea LaSalle (hymenoptera: eulophidae) under field conditions," Biological Control, vol. 49, no. 3, pp. 227-233, 2009.

[21] J. C. G. Torres, M. T. de la Cruz, M. P. de la Cruz, A. C. Perez, C. F. O. Garcia, and S. C. Garcia, "Caracterización de aislamientos nativos de Beauveria bassiana y su patogenicidad hacia Hypothenemus hampei, en Tabasco, México," Revista Colombiana de Entomología, vol. 42, pp. 28-35, 2016.

[22] S. Flores, S. Campos, A. Villaseñor et al., "Sterile males of Ceratitis capitata (diptera: tephritidae) as disseminators of Beauveria bassianaconidia for IPM strategies," Biocontrol Science and Technology, vol. 23, no. 10, pp. 1186-1198, 2013.

[23] A. Fauzantoro, Y. Muharam, and M. Gozan, "Improvement of nicotine yield by ethanolic heat reflux extraction of Nicotiana tabacum var. Virginia origin of ponorogo," International Journal of Applied Engineering Research, vol. 12, no. 23, pp. 13891-13897, 2017.

[24] M. Gozan, Y. Yasman, P. P. D. K. Wulan, and E. Dawitri, "Tobacco leaves pyrolysis for repellent active compound production," International Journal of Applied Engineering Research, vol. 9, pp. 9739-9749, 2014.

[25] A. Rodgman and T. A. Perfetti, The Chemical Constituents of Tobacco and Tobacco Smoke, CRC Press, New York, NY, USA, 2nd edition, 2013.

[26] R. V. Fant, A. R. Buchhalter, A. C. Buchman, and J. E. Henningfield, Nicotine Psychopharmacology. Handbook of Experimental Pharmacology, J. E. Henningfield, E. D. London, and S. Pogun, Eds., Springer, Berlin, Germany, 2009.

[27] R. C. Roger and B. J. R. Philogene, "Past and current prospects for the use of botanicals and plant allelochemicals in integrated pest management," Pharmaceutical Biology, vol. 46, no. 1-2, pp. 41-52, 2008.

[28] T. S. K. Dewi, H. Supartini, E. Suprapti et al., "Effect of Nicotiana tabacum extract concentration as biopesticide on protein content of robusta coffee beans and skin," in Proceedings of the International Conference on Science and Education and Technology, vol. 247, pp. 565-567, Semarang, Indonesia, August 2018.

[29] H. Haryuni, T. S. K. Dewi, E. Suprapti, S. F. Rahman, and M. Gozan, "The effect of Beauveria bassiana on the effectiveness of Nicotiana tabacum extract as biopesticide against Hypothenemus hampei to robusta coffee," International Journal of Technology, vol. 10, no. 1, pp. 159-166, 2019.

[30] S. A. H. Rizvi, S. Hussain, S. Rehman, S. Jaffar, and M. F. Rehman, "Efficacy of ecofriendly botanical extracts of ginger (Zingiber officinale), garlic (Allium sativum) and tobacco (Nicotiana tabacum L) for the control of cabbage looper (Trichoplusia binotalis) under agro ecological conditions of Peshawar, Pakistan," Journal of Entomology and Zoology Studies, vol. 4, pp. 88-90, 2016.

[31] H. N. Andjani, Y. Sentosa, K. Yati, M. Jufri, A. Fauzantoro, and M. Gozan, "Determination of LC50 value of Nicotiana tabacum L. extract against Gryllus bimaculatus imago and Galleria mellonella larvae," AIP Conference Proceedings, vol. 2193, no. 1, Article ID 030024, 2019.

[32] Y. Sentosa, H. N. Andjani, K. Yati, M. Jufri, Haryuni, and M. Gozan, "Determination of LC50 value of Nicotiana tabacum L. extract against Tenebrio molitor and Zophobas morio Larvae," AIP Conference Proceedings, vol. 2193, no. 1, Article ID 030021, 2019.

[33] B. Trianto and Y. Rosiyanti, Kabupaten Semarang Dalam Angka-2017, Indonesia Central Bureau of Statistics Regency of Semarang, Semarang, Indonesia, 2017. 
[34] L. P. Pedigo and M. E. Rice, Entomology and Pest Management, Waveland Press Inc, Illinois, IL, USA, 6th edition, 2014.

[35] A. Fauzantoro, A. Amatullah, Y. Muharram, and M. Gozan, "Production of Nicotiana tabacum L. extract: from laboratory-to pilot-scale and its antifungal activity against Aspergillus Niger," in Proceedings of Biotechnology International Congress (BIC), Bangkok, Thailand, September 2016.

[36] A. M. Hossain and S. M. Salehuddin, "Analytical determination of nicotine in tobacco leaves by gas chromatographymass spectrometry," Arabian Journal of Chemistry, vol. 6, no. 3, pp. 275-278, 2013.

[37] J. Shen and X. Shao, "Determination of tobacco alkaloids by gas chromatography-mass spectrometry using cloud point extraction as a preconcentration step," Analytica Chimica Acta, vol. 561, no. 1-2, pp. 83-87, 2006.

[38] L.-F. Huang, K.-J. Zhong, X.-J. Sun et al., "Comparative analysis of the volatile components in cut tobacco from different locations with gas chromatography-mass spectrometry (GC-MS) and combined chemometric methods," Analytica Chimica Acta, vol. 575, no. 2, pp. 236-245, 2006.

[39] J. C. Leffingwell, Tobacco: Production, Chemistry, and Technology, D. L. Davis and M. T. Nielsen, Eds., Blackwell Publishing Ltd., Oxford, UK, 1999.

[40] J. F. Barrera, Encyclopedia of Entomology, J. L. Capinera, Ed., Springer, Berlin, Germany, 2nd edition, 2008.

[41] A. M. Castro, J. Tapias, A. Ortiz, P. Benavides, and C. E. Góngora, "Identification of attractant and repellent plants to coffee berry borer,Hypothenemus hampei," Entomologia Experimentalis et Applicata, vol. 164, no. 2, pp. 120-130, 2017.

[42] S. Wiryadiputra, "Use of trapping for controlling of coffee berry borer (Hypothenemus hampei)," Pelita Perkebunan (Coffee and Cocoa Research Journal), vol. 22, no. 1, 2006.

[43] B. Mayer, "How much nicotine kills a human? Tracing back the generally accepted lethal dose to dubious self-experiments in the nineteenth century," Archives of Toxicology, vol. 88, no. 1, pp. 5-7, 2014.

[44] D. Matsushima, M. E. Prevo, and J. Gorsline, "Absorption and adverse effects following topical and oral administration of three transdermal nicotine products to dogs," Journal of Pharmaceutical Sciences, vol. 84, no. 3, pp. 365-369, 1995.

[45] P. Fantke, B. W. Gillespie, R. Juraske, and O. Jolliet, "Estimating half-lives for pesticide dissipation from plants," Environmental Science \& Technology, vol. 48, no. 15, pp. 8588-8602, 2014.

[46] H. N. Andjani, Y. Sentosa, K. Yati, A. Fauzantoro, M. Gozan, and Y. J. Yoo, "Acute oral toxicity test of Nicotiana tabacum L. bio-oil against female winstar rats," IOP Conference Series: Earth and Environmental Science, vol. 353, Article ID 012047, 2019. 